\title{
Effect of Liming on Soil Properties, Nutrient Content and Yield of Wetland Rice in Acid Tropical Soils of Kerala
}

\author{
Bhindhu, P. S. ${ }^{1}$, Sureshkumar P. ${ }^{2}$, Mini Abraham ${ }^{1}$ and E. K. Kurien ${ }^{1}$
}

\author{
${ }^{1}$ Agronomic Research Station, Kerala Agricultural University, Chalakudy, Thrissur, Kerala (680 307), India \\ ${ }^{2}$ Radiotracer Laboratory, College of Horticulture, Kerala Agricultural University Vellanikkara, Thrissur, Kerala (680 656), India
}

\section{Corresponding Author}

Bhindhu, P. S.

e-mail: bhindhu.ps@kau.in

\author{
Article History \\ Article ID: 3 C0786 \\ Received in $30^{\text {th }}$ October, 2017 \\ Received in revised form $19^{\text {th }}$ August, 2018 \\ Accepted in final form $31^{\text {st }}$ August, 2018
}

\begin{abstract}
The acid tropical soils of Kerala are characterized with low levels of basic cations and high levels of acidic cations like iron and manganese. Rice grown under flooded conditions are associated with high concentration of iron in the rhizosphere due to reduced soil environment. Higher iron content in the rhizosphere has antagonistic effect on uptake of essential nutrients leading to reduction of yield. An experiment was conducted in the first crop season of 2015 to study the influence of lime application on soil properties, plant nutrient content and yield of rice. The treatments included three sources of lime viz. calcium oxide, calcium carbonate and dolomite applied in three doses viz. as per POP recommendation, as per $\triangle \mathrm{pH}$ and as per lime requirement based on SMP buffer method and a control with no lime application. Application of calcium carbonate as per lime requirement based on SMP buffer method increased the soil pH from 4.90 to 7.10 at harvest of the crop when compared to 4.85 in the control plot. Lime applied as per lime requirement based on SMP buffer method increased the availability of potassium, calcium, sulphur and reduced the levels of available iron, manganese, copper and zinc. Content of potassium, calcium and sulphur in plant increased with dose of lime applied while the plant content of magnesium, iron, manganese, zinc and copper decreased. Application of dolomite increased the available magnesium in soil and the magnesium content in plant. Dolomite applied as per $\Delta \mathrm{pH}$ was found to be the optimum dose in increasing the yield of rice.
\end{abstract}

Keywords: Soil acidity, liming, nutrient content, wetland rice

\section{Introduction}

The state of Kerala exists as a narrow strip of land along the west coast of India sloping down from the high altitudes of Western Ghats through foot hills and mid land laterites to the coastal plains and further to deltaic deposits lying at or below mean sea level. The tropical humid climate prevalent in the state with bi-modal pattern of south-west and north-east monsoons resulted in leaching of bases and subsequent accumulation of iron, aluminium and manganese (Nair et al., 2011; Sureshkumar et al., 2018). Deficiency of basic cations and high saturation of soil CEC with $\mathrm{H}^{+}$and $\mathrm{Al}^{3+}$ ions is a problem inherent in these highly weathered soils that limit agricultural yields (Ryan et al., 2011; Nair et al., 2013). Rice grown under flooded conditions are associated with high concentration of iron in the rhizosphere due to reduced soil environment. Reduction of iron occurs within a few days due to absence of oxygen, resulting in enormous increase in concentration of ferrous $\left(\mathrm{Fe}^{2+}\right)$ ion. The iron content in rice leaves increased when the divalent cationic charge fraction in the soil solution accounted for by $\mathrm{Fe}^{2+}$ is high. The increase in the iron content in leaves occur at the expense of other cations like calcium and magnesium as the uptake of divalent cations by rice is non-specific(Moore and Patrick, 1989). When the availability of calcium is low, the plasma membrane initiates non-specific absorption. The function of the membrane is restored only with increase in availability of calcium thus increasing the absorption of other cations (Fageria, 2009). Higher concentration of $\mathrm{Fe}^{2+}$ in the rhizosphere has antagonistic effects on the uptake of essential nutrients which leads to reduction in rice yield (Fageria et al., 2008). The nutrient stress associated with iron toxicity in wetland rice can be suppressed with the use of balanced fertilizers (Patra and Mohanty, 1994).

Effective measures to ameliorate iron toxicity include periodic surface drainage and liming acid soils. Flooding tends to change the $\mathrm{pH}$ of soil to neutrality. This is mainly due to reduction of $\mathrm{Fe}$ and $\mathrm{Mn}$ oxides which consumes $\mathrm{H}^{+}$ ions (Fageria et al., 2011). Hence liming is a requisite for plant nutrition rather than $\mathrm{pH}$ correction in lowland rice. Lime acts as a source of calcium and/or magnesium and decreases acetate extractable Fe in soils (Seng et al., 2006). Calcium sufficiency in soil stimulates the absorption of $\mathrm{P}$ and $\mathrm{K}$ and 
accelerates translocation of photosynthetic products in rice (Kawasaki, 1995). Fertilization with nitrogen, phosphorus, potassium, calcium and magnesium is found to improve the iron excluding mechanism of rice.

With these considerations, current study was undertaken with an objective to study the influence of different liming material on the soil properties, plant nutrient content and yield of wetland rice.

\section{Materials and Methods}

\subsection{Experimental layout}

Field experiment was conducted at Regional Agricultural Research Station, Pattambi, Palakkad district, in the first cropping season of 2016. The climate is tropical sub humid to humid (mean annual temperature $27.6^{\circ} \mathrm{C}$; rainfall 1966 $\mathrm{mm}$ ) with a dry period of around five months. The soil is sandy clay loam in texture with $\mathrm{pH}$ 4.9. The experiment was laid out in randomised block design with three replications. Ten treatments were imposed that included three sources of liming material applied at three doses with one control treatment. The three sources included calcium oxide $\left(S_{1}\right)$, calcium carbonate $\left(S_{2}\right)$ and dolomite $\left(S_{3}\right)$. The three doses included (i) application as per package of practices recommendations ( $600 \mathrm{~kg} \mathrm{ha}^{-1}$ of $\mathrm{CaCO}_{3}$ ) of Kerala Agricultural University $\left(\mathrm{L}_{1}\right)(\mathrm{KAU}, 2011)$ (ii) as per $\Delta \mathrm{pH}$ (6.5-measured $\mathrm{pH}$ $x 0.3375 \mathrm{t} \mathrm{ha}^{-1}$ of $\left.\mathrm{CaCO}_{3}\right)\left(\mathrm{L}_{2}\right)(\mathrm{DOA}, 2013)$ (iii) as per lime requirement based on SMP buffer method $\left(\mathrm{L}_{3}\right)$ (Shoemaker et al., 1961). The different liming materials were applied based on their calcium carbonate equivalents, which were $137 \%$ for calcium oxide, $97 \%$ for calcium carbonate and $99 \%$ for dolomite (Table 1).

\subsection{Crop culture}

Jyothi, a short duration variety of 110-120 days was used for the study. Plots of $5 \times 4 \mathrm{~m}^{2}$ were prepared by constructing bunds of $30 \mathrm{~cm}$ width and height. Fertilizers were given as per the package of practices recommendations of Kerala Agricultural University, modified based on soil test results. Liming materials were applied in two splits. The first split was applied as basal dose, and the second as top dressing one week before panicle initiation.

The crop was harvested from each plot and the weight of straw and grain was recorded separately and expressed as t ha-1.

\subsection{Collection and analysis of soil and plant samples}

Rhizosphere soil samples $(0-15 \mathrm{~cm})$ were drawn from each plot at harvest, dried under shade, sieved through $2 \mathrm{~mm}$ sieve and analysed for available nutrients using standard procedures. Plant samples were collected from each plot at harvest stage, washed and dried to constant weight, powdered in stainless steel grinder, digested with di-acid mixture $\left(\mathrm{HNO}_{3}\right.$ and $\left.\mathrm{HClO}_{4} 4: 1\right)$ and analysed for nutrient content using standard procedures.

\subsection{Statistical analysis}

The experimental data were analysed as factorial Randomised
Table 1: Treatment combinations and quantity of liming material added

\begin{tabular}{|c|c|c|c|}
\hline $\begin{array}{l}\text { Treatment } \\
\text { combina- } \\
\text { tion }\end{array}$ & Source used & Dose & $\begin{array}{l}\text { Quantity } \\
\text { applied } \\
(\mathrm{t} \mathrm{ha-1})\end{array}$ \\
\hline $\mathrm{S}_{1} \mathrm{~L}_{1}$ & Calcium oxide & $\begin{array}{l}\text { As per POP rec- } \\
\text { ommendationsof } \\
\text { Kerala Agricultural } \\
\text { University }\end{array}$ & 0.438 \\
\hline $\mathrm{S}_{1} \mathrm{~L}_{2}$ & Calcium oxide & As per $\Delta \mathrm{pH}$ & 0.394 \\
\hline $\mathrm{S}_{1} \mathrm{~L}_{3}$ & Calcium oxide & $\begin{array}{l}\text { As per lime require- } \\
\text { ment based on } \\
\text { SMP buffer method }\end{array}$ & 3.905 \\
\hline $\mathrm{S}_{2} \mathrm{~L}_{1}$ & $\begin{array}{l}\text { Calcium car- } \\
\text { bonate }\end{array}$ & $\begin{array}{l}\text { As per POP recom- } \\
\text { mendations }\end{array}$ & 0.619 \\
\hline $\mathrm{S}_{2} \mathrm{~L}_{2}$ & $\begin{array}{l}\text { Calcium car- } \\
\text { bonate }\end{array}$ & As per $\Delta \mathrm{pH}$ & 0.557 \\
\hline $\mathrm{S}_{2} \mathrm{~L}_{3}$ & $\begin{array}{l}\text { Calcium car- } \\
\text { bonate }\end{array}$ & $\begin{array}{l}\text { As per lime require- } \\
\text { ment based on } \\
\text { SMP buffer method }\end{array}$ & 5.516 \\
\hline $\mathrm{S}_{3} \mathrm{~L}_{1}$ & Dolomite & $\begin{array}{l}\text { As per POP recom- } \\
\text { mendations }\end{array}$ & 0.606 \\
\hline $\mathrm{S}_{3} \mathrm{~L}_{2}$ & Dolomite & As per $\Delta \mathrm{pH}$ & 0.545 \\
\hline $\mathrm{S}_{3} \mathrm{~L}_{3}$ & Dolomite & $\begin{array}{l}\text { As per lime require- } \\
\text { ment based on } \\
\text { SMP buffer method }\end{array}$ & 5.404 \\
\hline Control & $\mathrm{Nil}$ & Nil & 0 \\
\hline
\end{tabular}

Block Design with the sources and doses of liming materials as the main factors. In addition to include the control treatment the data were analysed as complete RBD with ten treatments and the effects of treatments were assessed by analyzing the data as a $3^{2}+1$ experiment.

\section{Results and Discussion}

The quantity of liming materials added was based on their calcium carbonate equivalents. The sources used (calcium oxide, calcium carbonate and dolomite) basically differed in their solubility and reactivity for neutralizing soil acidity. While burnt lime and limestone acted as sources of calcium, dolomite added both calcium and magnesium to soil. The effect of liming on electrochemical properties and available nutrient content in the soil are presented in Table 2.

\subsection{Soil $\mathrm{pH}$}

The different sources and doses of liming materials added had significant effect on $\mathrm{pH}$ of soil. The treatment combinations with dose as per SMP buffer method $\left(\mathrm{L}_{3}\right)$ recorded significantly higher soil pH. SMP buffer method of lime requirement estimates the quantity of lime required to neutralize the total 


\begin{tabular}{|c|c|c|c|c|c|c|c|}
\hline \multirow[t]{3}{*}{ Treatment combinations } & \multirow[t]{3}{*}{ soil pH } & \multicolumn{6}{|c|}{ Available nutrients } \\
\hline & & Phosphorus & Potassium & Calcium & Magnesium & Iron & Manganese \\
\hline & & \multicolumn{2}{|c|}{$\mathrm{kg} \mathrm{ha}^{-1}$} & \multicolumn{4}{|c|}{$\mathrm{mg} \mathrm{kg}^{-1}$} \\
\hline $\mathrm{S}_{1} \mathrm{~L}_{1}$ & 4.94 & 12.46 & 65.17 & 246.97 & 30.52 & 218.87 & 16.15 \\
\hline$S_{1} L_{2}$ & 4.94 & 12.44 & 62.27 & 223.97 & 30.61 & 219.23 & 16.10 \\
\hline $\mathrm{S}_{1} \mathrm{~L}_{3}$ & 6.42 & 13.50 & 68.96 & 1000.25 & 24.71 & 178.60 & 14.39 \\
\hline $\mathrm{S}_{2} \mathrm{~L}_{1}$ & 5.04 & 12.72 & 65.83 & 350.92 & 30.86 & 185.87 & 16.33 \\
\hline $\mathrm{S}_{2} \mathrm{~L}_{2}$ & 5.05 & 13.06 & 64.76 & 340.82 & 32.26 & 218.87 & 16.49 \\
\hline $\mathrm{S}_{2} \mathrm{~L}_{3}$ & 7.10 & 12.42 & 70.23 & 2403.70 & 29.78 & 168.93 & 14.47 \\
\hline $\mathrm{S}_{3} \mathrm{~L}_{1}$ & 4.97 & 12.32 & 62.67 & 235.83 & 60.46 & 235.65 & 17.05 \\
\hline $\mathrm{S}_{3} \mathrm{~L}_{2}$ & 5.02 & 11.94 & 65.74 & 228.73 & 57.40 & 250.07 & 17.65 \\
\hline $\mathrm{S}_{3} \mathrm{~L}_{3}$ & 6.02 & 12.97 & 69.32 & 797.27 & 141.67 & 207.43 & 15.79 \\
\hline$p<0.05$ & 0.10 & 0.25 & 0.56 & 342.37 & 6.26 & 7.70 & 0.95 \\
\hline Control & 4.85 & 12.02 & 55.88 & 145.87 & 31.83 & 269.40 & 17.12 \\
\hline F statistic (Treatments vs control) & $79.3^{* *}$ & $35.71^{* *}$ & $151.15^{* *}$ & $19.54^{* *}$ & $85.97^{* *}$ & $363.6^{* *}$ & $11.41^{* *}$ \\
\hline
\end{tabular}

${ }^{* *} p<0.01$

acidity, whereas the lime applied as per $\Delta \mathrm{pH}$ neutralizes only the active acidity. The quantity of liming material added as per dose $L_{3}$ is much higher than the other two doses, and hence a considerable increase in soil $\mathrm{pH}$ was recorded. The application of calcium carbonate as per the lime requirement $\left(\mathrm{S}_{2} \mathrm{~L}_{3}\right)$ increased the soil pH from 4.90 to 7.10 and was significantly superior over other treatment combinations, while in the control plot the $\mathrm{pH}$ decreased to 4.85 .

\subsection{Available phosphorus}

The initial status of available $P$ in soil was $12.05 \mathrm{~kg} \mathrm{ha}^{-1}$. The treatments imposed were found to increase the available phosphorus content in soil when compared to the control plot. This might be because of the formation of mono or di calcium phosphates which are more soluble. Fageria et al. (1995) reported an increase of soil phosphorus as $\mathrm{pH}$ increased from 5.0 to 6.5, due to release of $\mathrm{P}$ ions from $\mathrm{Al}$ and Fe oxides.

\subsection{Available potassium}

Available potassium in the control plot decreased significantly from the initial status of $74.88 \mathrm{~kg} \mathrm{ha}^{-1}$ to $55.88 \mathrm{~kg} \mathrm{ha}^{-1}$. The potassium content in the control plot was significantly lower than the lime treated plots. Calcium from the liming materials added would have replaced potassium from the exchange sites thus increasing the labile pool. Available potassium was significantly higher in the treatment where calcium carbonate was applied as per lime requirement $\left(\mathrm{S}_{2} \mathrm{~L}_{3}\right)$. In soils with $\mathrm{pH}$ dependent charges, increase in $\mathrm{pH}$ with liming enhances the CEC of soil thus improving the ability to retain potassium (Ernani et al., 2012).

\subsection{Available calcium}

The initial status of available calcium was $181.85 \mathrm{mg} \mathrm{kg}^{-1}$.
The application of liming materials significantly increased the available status of calcium in soil while the availability of calcium decreased to $145.87 \mathrm{mg} \mathrm{kg}^{-1}$ in the control plot. The application of calcium carbonate as per lime requirement $\left(\mathrm{S}_{2} \mathrm{~L}_{3}\right)$ was significantly superior with respect to availability of calcium over all other treatment combinations. This was concurrent to the significantly higher $\mathrm{pH}$ recorded in this treatment.

\subsection{Available magnesium}

The initial status of available magnesium was $36.28 \mathrm{mg}$ $\mathrm{kg}^{-1}$. Application of different doses of dolomite $\left(\mathrm{S}_{3}\right)$ could significantly influence the available magnesium status in soil and was superior over the other two sources of liming materials added. The applied dolomite with 10.4 per cent magnesium could improve the magnesium status in soil due to slow release on account of low solubility, whereas application of soluble magnesium sulphate in other treatments would have led to loss of magnesium. As magnesium is unable to replace other cations like calcium from the exchange complex, it is compelled to remain in solution thus leading to loss. Highest magnesium content was recorded in treatment with dolomite applied as per lime requirement $\left(\mathrm{S}_{3} \mathrm{~L}_{3}\right)$ due to the higher quantity of dolomite applied.

\subsection{Available iron and manganese}

The available iron in the control plot increased from the initial status of $235.70 \mathrm{mg} \mathrm{kg}^{-1}$ to $269.40 \mathrm{mg} \mathrm{kg}^{-1}$ which can be attributed to the reduction of ferric to ferrous form due to flooding. The available manganese content also increased from the initial status of 13.43 to $17.12 \mathrm{mg} \mathrm{kg}^{-1}$ in the control plot. The decrease in the status of available Fe and $\mathrm{Mn}$ found in the treatments where liming materials were added can 
be attributed to the exchange of reduced ferrous iron and manganous ion from the exchange sites by $\mathrm{Ca}$ added through lime and its subsequent precipitation. Precipitation of $\mathrm{Fe}^{2+}$ as $\mathrm{Fe}_{3} \mathrm{O}_{4} \cdot \mathrm{nH}_{2} \mathrm{O}$ and $\mathrm{Mn}$ as $\mathrm{MnCO}_{3}$ under flooded condition was reported by Ponnamperuma (1972). Application of calcium carbonate as per lime requirement $\left(\mathrm{S}_{2} \mathrm{~L}_{3}\right)$ was found effective in significantly reducing the content of available Fe in soil. This is also concurrent to the increase in $\mathrm{pH}$ of soil recorded in this treatment.

\subsection{Plant nutrient content}

The nutrient content in the straw and grain are presented in
Tables 3 and 4 . Nitrogen content in straw was significantly higher in the treatments where calcium carbonate and dolomite were applied as per lime requirement. The nitrogen content in grain however was not significantly influenced by the different sources and doses of lime. The lack of any significant difference in the nitrogen content in grain might be due to the mobility of nitrogen and resultant translocation. The phosphorus content in the straw and grain was significantly lowest in the treatment where calcium carbonate was applied as per lime requirement $\left(\mathrm{S}_{2} \mathrm{~L}_{3}\right)$. The potassium content in the straw was significantly higher in the treatment where dolomite was applied as per lime requirement,

\begin{tabular}{lcccccc}
\hline \multicolumn{2}{l}{ Table 3: Effect of treatment combinations on primary nutrient content (\%) in plant } \\
\hline Treatment combinations & \multicolumn{3}{c}{ Nitrogen } & Phosphorus & \multicolumn{3}{c}{ Potassium } \\
\cline { 2 - 7 } & Straw & Grain & Straw & Grain & Straw & Grain \\
\hline $\mathrm{S}_{1} \mathrm{~L}_{1}$ & 0.69 & 1.24 & 0.110 & 0.32 & 1.30 & 0.28 \\
$\mathrm{~S}_{1} \mathrm{~L}_{2}$ & 0.70 & 1.21 & 0.108 & 0.33 & 1.28 & 0.30 \\
$\mathrm{~S}_{1} \mathrm{~L}_{3}$ & 0.77 & 1.27 & 0.102 & 0.32 & 1.34 & 0.29 \\
$\mathrm{~S}_{2} \mathrm{~L}_{1}$ & 0.73 & 1.25 & 0.098 & 0.29 & 1.31 & 0.29 \\
$\mathrm{~S}_{2} \mathrm{~L}_{2}$ & 0.67 & 1.25 & 0.104 & 0.30 & 1.28 & 0.31 \\
$\mathrm{~S}_{2} \mathrm{~L}_{3}$ & 0.82 & 1.26 & 0.091 & 0.28 & 1.34 & 0.30 \\
$\mathrm{~S}_{3} \mathrm{~L}_{1}$ & 0.66 & 1.23 & 0.116 & 0.32 & 1.35 & 0.29 \\
$\mathrm{~S}_{3} \mathrm{~L}_{2}$ & 0.69 & 1.22 & 0.112 & 0.32 & 1.40 & 0.29 \\
$\mathrm{~S}_{3} \mathrm{~L}_{3}$ & 0.81 & 1.23 & 0.108 & 0.34 & 1.45 & 0.27 \\
$p<0.05$ & 0.04 & 0.04 & 0.016 & 0.02 & 0.10 & $\mathrm{NS}$ \\
Control & 0.55 & 1.22 & 0.123 & 0.30 & 1.32 & 0.29 \\
F statistic (Treatments vs control) & $176^{* *}$ & 3.70 & $16.67^{* *}$ & 0.01 & $5.67^{*}$ & 3.23 \\
\hline
\end{tabular}

${ }^{* *} p<0.01 ;{ }^{*} p<0.05$

\begin{tabular}{|c|c|c|c|c|c|c|c|c|}
\hline \multirow[t]{2}{*}{ Treatment combinations } & \multicolumn{2}{|c|}{ Calcium } & \multicolumn{2}{|c|}{ Magnesium } & \multicolumn{2}{|l|}{ Iron } & \multicolumn{2}{|c|}{ Manganese } \\
\hline & Straw & Grain & Straw & Grain & Straw & Grain & Straw & Grain \\
\hline $\mathrm{S}_{1} \mathrm{~L}_{1}$ & 6280 & 238.73 & 1077 & 1404 & 444.07 & 311.18 & 375.55 & 41.33 \\
\hline$S_{1} L_{2}$ & 6219 & 235.87 & 1075 & 1397 & 447.84 & 319.87 & 372.93 & 37.23 \\
\hline $\mathrm{S}_{1} \mathrm{~L}_{3}$ & 6674 & 416.80 & 1070 & 1413 & 409.53 & 292.70 & 368.73 & 35.63 \\
\hline $\mathrm{S}_{2} \mathrm{~L}_{1}$ & 6097 & 236.57 & 1020 & 1418 & 425.50 & 312.50 & 362.62 & 37.90 \\
\hline $\mathrm{S}_{2} \mathrm{~L}_{2}$ & 5561 & 237.77 & 1018 & 1411 & 432.80 & 316.77 & 370.22 & 37.15 \\
\hline $\mathrm{S}_{2} \mathrm{~L}_{3}$ & 6120 & 402.47 & 995 & 1415 & 398.30 & 290.23 & 296.20 & 34.63 \\
\hline $\mathrm{S}_{3} \mathrm{~L}_{1}$ & 5227 & 224.90 & 1032 & 1424 & 483.37 & 315.24 & 410.90 & 38.12 \\
\hline $\mathrm{S}_{3} \mathrm{~L}_{2}$ & 5215 & 206.50 & 1030 & 1424 & 486.73 & 316.90 & 416.67 & 40.07 \\
\hline $\mathrm{S}_{3} \mathrm{~L}_{3}$ & 5427 & 369.20 & 1147 & 1444 & 429.90 & 304.82 & 374.10 & 36.87 \\
\hline$p<0.05$ & 189.93 & 9.84 & 44.38 & 25.80 & 10.97 & 11.52 & 18.42 & 2.42 \\
\hline Control & 5210.33 & 229.87 & 1040 & 1309 & 520.10 & 312.37 & 405.27 & 36.07 \\
\hline F statistic (Treatments vs control) & $181.38^{* *}$ & $316.40^{* *}$ & $386.42^{* *}$ & $61.94^{* *}$ & $56.71^{* *}$ & $24.08^{* *}$ & $26.29^{* *}$ & 0.89 \\
\hline
\end{tabular}

${ }^{* *} p<0.01 ;{ }^{*} p<0.05$ 
whereas potassium content in the grain was not found to be significantly influenced by the different sources and doses of liming materials added. Calcium content in the straw and grain was significantly higher in the treatment where calcium oxide was applied as per lime requirement $\left(\mathrm{S}_{1} \mathrm{~L}_{3}\right)$ which might be because of the higher solubility of calcium oxide making calcium more available in the initial stages of plant growth leading to higher plant absorption. Magnesium content in the straw and grain was significantly higher in the treatment where dolomite was applied as per lime requirement $\left(\mathrm{S}_{3} \mathrm{~L}_{3}\right)$ which is concurrent to the higher available magnesium status recorded in this treatment. Iron content in straw was significantly lower in the treatment where calcium carbonate was applied as per lime requirement while calcium oxide and calcium carbonate applied as per lime requirement recorded significantly lower iron content in grain.

\subsection{Grain and straw yield}

The data on biometric observations viz., number of productive tillers, the number of grains per panicle, thousand grain weight, straw and grain yield are presented in Table 5 . The yield in the control plot was significantly lower than the plots where different treatments were imposed, indicating the beneficial influence of liming on the yield of rice. The data on number of productive tillers, grains per panicle, thousand grain weight and grain yield confers that application of dolomite as per $\Delta \mathrm{pH}$ was the optimum dose of liming material to significantly increase crop yield.

Table 5: Effect of treatment combinations on biometric observations and yield of rice

\begin{tabular}{|c|c|c|c|c|c|}
\hline Treatment combinations & $\begin{array}{l}\text { No. of produc- } \\
\text { tive tillers }\end{array}$ & $\begin{array}{c}\text { No. of grains } \\
\text { panicle }^{-1}\end{array}$ & $\begin{array}{c}\text { Thousand grain } \\
\text { weight (g) }\end{array}$ & $\begin{array}{c}\text { Grain yield } \\
\left(\mathrm{t} \mathrm{ha}^{-1}\right)\end{array}$ & $\begin{array}{c}\text { Straw yield } \\
\left(\mathrm{t} \mathrm{ha}^{-1}\right)\end{array}$ \\
\hline $\mathrm{S}_{1} \mathrm{~L}_{1}$ & 7.50 & 105.97 & 27.29 & 5.43 & 6.62 \\
\hline $\mathrm{S}_{1} \mathrm{~L}_{2}$ & 7.50 & 105.27 & 27.40 & 5.43 & 6.68 \\
\hline $\mathrm{S}_{1} \mathrm{~L}_{3}$ & 7.61 & 106.23 & 27.08 & 5.48 & 6.79 \\
\hline $\mathrm{S}_{2} \mathrm{~L}_{1}$ & 7.47 & 105.18 & 27.36 & 5.42 & 6.75 \\
\hline $\mathrm{S}_{2} \mathrm{~L}_{2}$ & 7.50 & 105.11 & 27.39 & 5.40 & 6.73 \\
\hline $\mathrm{S}_{2} \mathrm{~L}_{3}$ & 7.48 & 105.26 & 26.95 & 5.46 & 6.55 \\
\hline $\mathrm{S}_{3} \mathrm{~L}_{1}$ & 7.63 & 107.27 & 27.51 & 5.46 & 6.72 \\
\hline $\mathrm{S}_{3} \mathrm{~L}_{2}$ & 7.60 & 107.47 & 27.50 & 5.46 & 6.78 \\
\hline $\mathrm{S}_{3} \mathrm{~L}_{3}$ & 7.67 & 107.98 & 27.02 & 5.51 & 6.70 \\
\hline$p<0.05$ & 0.09 & 0.55 & 0.12 & 0.05 & 0.06 \\
\hline Control & 7.45 & 103.90 & 27.25 & 5.38 & 6.47 \\
\hline F statistic (Treatments vs control) & $118.88^{* *}$ & $27.61^{* *}$ & $12^{* *}$ & $48.00^{* *}$ & $215^{* *}$ \\
\hline
\end{tabular}

${ }^{* *} p<0.01 ;{ }^{*} p<0.05$

\section{Conclusion}

Application of liming material reduced the content of acidic cations in soil as well as in plant, concomitant to the quantity applied. Whereas, the yield contributing characters revealed that application of dolomite as per $\Delta \mathrm{pH}$ was optimum. A moderate amount of liming material is sufficient to ameliorate the toxicity of acidic cations. Application of dolomite could maintain a balance between the calcium and magnesium content in soil as well as improve the uptake of magnesium by the crop.

\section{Acknowledgement}

The authors acknowledge Kerala Agricultural University, Thrissur, Kerala for providing all the facilities for this work.

\section{References}

DOA (Department of Agriculture), 2013. Manual on Soil, Plant and Water analysis.Vol. 1. Venugopal, V.K., Nair, K.M.,
Vijayan, M.R., Susan John, K., Sureshkumar P., Ramesh C. R. (Eds), Government of Kerala, 157.

Ernani, P.R., Mantovani, A., Scheidt, F.R., Nesi, C., 2012. Liming decreases the vertical mobility of potassium in acidic soils. Communications in Soil Science and Plant Analysis 43(19), 2544-2549.

Fageria, N.K., 2009. The Use of Nutrients in Crop Plants. CRC Press, Taylor and Francis Group, London, 430. Fageria, N. K., Santos, A.B., Coelho, A.M., 2011. Growth, yield and yield components of lowland rice as influenced by ammonium sulfate and urea fertilization. Journal of Plant Nutrition 34(3), 371-386.

Fageria, N.K., Santos, A.B., Filho, M.P.B., Guimaraes, C.M., 2008. Iron toxicity in lowland rice. Journal of Plant Nutrition 31, 1676-1697.

Fageria, N. K., Zimmermann, F.J.P., Baligar, V.C., 1995. Lime and phosphorus interations on growth and nutrient uptake by upland rice, wheat, common bean, and corn in an Oxisol. Journal of Plant Nutrition 18(11), 2516-2532. 
KAU (Kerala Agricultural University), 2011. Package of Practices Recommendations: Crops (14 ${ }^{\text {th }}$ Edn.). Kerala Agricultural University, Thrissur, 360.

Kawasaki, T., 1995. Science of rice plant: physiology. In: Matsuo, T., Kumazawa K., Ishii, R., Ishihara, K., Hirata, H. (Eds.), Metabolism and Physiology of Calcium and Magnesium (Vol. 2). Food and Agricultural Policy Research Center, Tokyo, Japan, 391-395.

Moore, P.A., Patrick, W.H., 1989. Calcium and magnesium availability and uptake by rice in acid sulphate soils. Soil Science Society of America Journal 53, 816-822.

Nair, K.M., Anilkumar, K.S., Srinivas, S., Sujatha, K., Venkatesh, D.H., Naidu, L.G.K., Sarkar, D., Rajasekharan, P., 2011. Agro-ecology of Kerala. NBSS Publ. No. 1038. National Bureau of Soil Survey and Land Use Planning, Nagpur, India, 408.

Nair, K.M., Sureshkumar, P., Narayanankutty, M.C., 2013. Soils of Kerala. In: Rajasekharan, P., Nair, K.M., Rajasree, G., Sureshkumar, P., Narayanankutty, M.C. (Eds.), Soil Fertility Assessment and Information Management for Enhancing Crop Productivity in Kerala. Kerala State Planning Board, Thiruvananthapuram, 72-92.

Patra, B.N., Mohanty, S.K., 1994. Effect of nutrients and liming on changes in $\mathrm{pH}$, redox potential, and uptake of iron and manganese by wetland rice in iron-toxic soil. Biology and Fertility of Soils 17, 285-288.

Ponnamperuma, F.N., 1972. The chemistry of submerged soils. Advances in Agronomy 24, 29-96.

Ryan, P.R., Tyerman, S.D., Sasaki, T., Furuichi, T., Yamamoto, Y., Zhang, W.H., Delhaize, E., 2011. The identification of aluminium-resistance genes provides opportunities for enhancing crop production on acid soils. Journal of Experimental Botany 62, 9-20.

Shoemaker, H.E., McLean, E.O., Pratt, P.F., 1961. Buffer methods for determination of lime requirements of soils with appreciable amounts of exchangeable aluminum. Soil Science Society of America Proceedings 25, 274-277.

Sureshkumar, P., Geetha, P., Bhindhu, P.S., 2018. Chemistry and fertility-Management of humid tropical soils of Kerala as influenced by topography and climate. Indian Journal of Fertilisers 14(3), 30-44.

Seng, V., Bell, R.W., Willett, I.R., 2006. Effect of lime and flooding on phosphorus availability and rice growth on two acidic lowland soils. Communications in Soil Science and Plant Analysis 37, 313-336. 